\title{
Correspondence
}

http://dx.doi.org/10.11646/phytotaxa.174.2.9

\section{New combinations in Balkans Clinopodium (Lamiaceae)}

\author{
DUILIO IAMONICO ${ }^{*} \&$ SANDRO BOGDANOVIĆ ${ }^{2}$ \\ ${ }^{1}$ Laboratory of Phytogeography and Applied Geobotany, Section Environment and Landscape, Department DPTA, University of Rome \\ Sapienza,00196 Roma, Italy; email: d.iamonico@yahoo.it \\ ${ }^{2}$ Department of Agricultural Botany, Faculty of Agriculture, University of Zagreb, Svetošimunska 25, HR-10000 Zagreb, Croatia \\ * author for correspondence
}

To accommodate the morphological diversity of Satureja s.l. (Lamiaceae, Nepetoideae, Menthae, Menthinae), many taxonomists (Bentham 1848, Boissier 1879, Ball \& Getliffe 1972, Davis 1982) assign the species of this genus to different genera, mainly Satureja Linnaeus (1753: 587), Clinopodium Linnaeus (1753: 587), Acinos Miller (1754: without pagination), Calamintha Miller (1754: without pagination), and Micromeria Bentham (1829: ad tab 1282, no. 17), while others recognize only Satureja (e.g., Greuter et al. 1984) or Clinopodium (e.g., Kuntze 1891). Recent molecular studies (Wagstaff \& al. 1995, Prether \& al. 2002, Harley \& al. 2004, Trusty \& al. 2004, Bräuchler \& al. 2005) have contributed to a better understanding of the group and they favoured abandonment of the concept of Satureja sensu lato. As consequence, the genera Acinos, Calamintha and Micromeria p.p. were transferred to the genus Clinopodium and several new combinations were validated both for the Americas (Cantino \& Wagstaff 1998, Govaerts 1999, Harley \& Paucar 2000, Pool 2008) and for Europe (Rosselló 2006, Bräuchler \& al. 2008a, 2008b, Peruzzi \& Conti 2008, Brullo \& Brullo 2009, Bartolucci \& Conti, 2011, 2012).

Concerning the genus Acinos, the Balkan A. alpinus (Linnaeus 1753: 591-592) Moench (1794: 407) subsp. dinaricus Šilić (1979: 274) and Melissa majoranifolia Miller (1768: without page) were not transferred to Clinopodium and the following new combinations are therefore necessary. For nomenclatural purposes, the names M. majoranifolia Miller (1768: without page) and Thymus patavinum Jacquin (1771: 7) are discussed and typified.

Clinopodium alpinum (L.) Merino subsp. dinaricum (Šilić) Iamonico \& Bogdanović, comb. nov.

Basionym: Acinos alpinus (L.) Moench subsp. dinaricus Šilić (1979: 274). Type:-BOSNIA-HERZEGOVINA, Sarajevo, Ravna planina (Jahorina), in monte Hum, about 1400 m, 11 Jul 1939, K. Malý (holotype, SARA).

Clinopodium majoranifolium (Miller) Iamonico \& Bogdanović, comb. nov.

Basionym: Melissa majoranifolia Miller (1768: without page). Type (lectotype, designated here):-ITALY. Veneto, Padova, Botanical Garden, P. Miller s.n. (BM-0000999967!). (Fig. 1)

Thymus patavinum Jacquin (1771: 7). Type (lectotype, designated here):-ITALY. Boccone (1697): [icon] Clinopodium perenne Pulegii odore $B B B$, Tab. 45 , fig. B.

Notes:-Melissa majoranifolia was first described by Miller (1768: without page) who provided a short diagnosis (in Latin and English), plus a synonym ("Calamintha Romana, majoranae folio, pulegi odore") cited from Boccone (1697); a description, including flowering time (“...July and August...”), propagation mode (“...by seeds...by cuttings...”), and provenance ("...grows naturally in Italy"), are also given. Boccone (p. 58-59) discussed the members of Calamintha citing a "Calamintha montana, pulegi odore" (page 58) followed by a long description and the provenance: “...nella Pieve di Quero, non molto lontano dalla città di Belluno...nello Stato Veneto...à Saffi...sopra il Fiume Piave...trà il Villaggio di Vasso, e la Terra di Alano" [“...in Pieve di Quero, not far from the city of Belluno... in the Venetian State... in Saffi...on the river Piave... between the Village fo Vasso, and the Terra di Alano" (Belluno is a city of Veneto region, north-easter Italy)]; at page 59 Boccone named the plant as "Cliopodium pulegi odore". A third taxon ("Clinopodium minus, angustifolium Pulegii odore, Romanum") was mentioned at page 50, with the provenance "Nasce nelle Campagne di Tivoli, e nello stato di Siena..." ["It is born in the rural ares of Tivoli, and in the State of Siena..."; Tivoli and Siena are towns of respectively the regions Lazio, and Tuscany in central Italy]; an iconography is associated with the latter polynomial. Examining Boccone's index (page 179) to the figures, two members of Calamintha are 
php?Libro $=3301 \&$ Hojas) includes five pieces of plants that are referred to three polynomials, as clearly indicated: "Clinopodium minus Pulegy odore Romanum" (the plant on the left of the plate, marked as "A"), "Clinopodium montanum Casp. Bauh." (the little piece on the top-left of the plate, marked as "C"), and "Clinopodium perenne Pulegy odore $B B B$ " (the three parts on the top-center, center, and bottom-right of the plate, marked as " $B$ "). None of these polynomials match Miller's synonym, although those associated with the figures " $A$ " and " $B$ " partially correspond, but the word "minus" by Boccone (figure " $A$ ") does not occur in the Miller's synonym, while "perenne" (figure " $B$ ") is in contrast with the Miller's concept of his M. majoranifolia who stated that "...this is a biennal [sic] plant..."). Moreover, the plant " $A$ " shows features that do not match Miller's diagnosis both as to leaves shape ["...folii ovatis.." inasmuch as the Boccone's image shows lanceolate leaves] and in the inflorescence [ "...floribus verticillatis..." while the Boccone image shows solitary flowers]. Thus, the Miller's statement "Calamintha Romana, majoranae folio, pulegi odore" is ambiguous and cannot be applied to any of the Boccone's images. The only sure match is Boccone's (p. 50) "Clinopodium minus, angustifolium Pulegii odore, Romanum" that, unfortunately, is not linked to an image, and therefore cannot be used for the lectotypification of M. majoranifolia since a type must be a specimen or an illustration (Art. 9.2 of the ICN, McNeill et al. 2012). All things considered, none of the Boccone images can be considered original material, and thus none is eligible for lectotypification. Boccone's figure " $B$ ", that matches Miller's diagnosis, could be considered a neotype if no original material could be found (Art. 9.7 of the ICN, McNeill et al. 2012). Miller (1768) probably wrongly interpreted Boccone's discussion and figures. In fact, Boccone (1697: 57-61), in a section entitled "Osservatione Settima...Intorno ad alcune altre piante, con odore di Pulegio, osservate in Roma" ["Seventh Observation...Around some other plants, with smell of Pulegio, observed in Rome"]) discussed another plant [alien according to Boccone ("...una Pianta straniera, ed exotica..." that means "... a alien plant, exotic...")], named "Clinopodium perenne, Patavinum Ocymi subrotundo folio, Pulegii odore" that was cultivated at the Botanical Garden of Padova (Veneto region, North-Eastern Italy) according to the author. The figure " $B$ " of Plate 45 is probably representative of this polynomial. There is one specimen at BM (barcode 0000999967) that bears six pieces of the same plant whose features match the Miller's description. The sheet represents the only extant original material and it is selected here as lectotype of the name Melissa majoranifolia.

It is interesting to note that about 70 years after Boccone, Jacquin (1771: 7) described a new species, Thymus patavinus, providing a short diagnosis ("THYMUS floribus verticillatis; pedunculis unifloris; caulibus ramosis, adscententibus; foliis subserratis") and citing a synonym from Boccone (1697), namely "Clinopodium perenne, pulegi odore, Majoranae folio, Patvinum. Bocc. mus. tab. 45. fig. B". The cited Boccone's image matches Jacquin's protologue and is there designated as the lectotype of T. patavinum.

Comparing Miller's specimen (lectotype of Melissa majoranifolia), and the image by Boccone (lectotype of Thymus patavinus), we conclude that these names are heterotypic synonyms as already proposed by recent authors (e.g., World Checklist of Selected Plant Families 2010).

\section{Acknowledgement}

We are grateful to J. L. Reveal (Cornell University, Ithaca, USA) for useful discussion about Boccone's work, and to C. E. Jarvis (London), and J. Wajer (Natural History Museum, London) for the permission to reproduce the image of the Miller's specimen.

\section{References}

Ball, P.W. \& Getliffe, F.M. (1972) Satureja, Acinos, Clinopodium, Calamintha. In: Tutin, T.G., Heywood, V.H., Burges, N.A., Moore, D.M., Valentine, D.H., Walters, S.M. \& Webb, D.A. (Eds.) Flora europea 3. Cambridge University Press, Cambridge pp. $163-167$.

Bartolucci, F. \& Conti, F. (2011) Notula 1821. Notulae alla checklist della Flora vascolare italiana: 11. Informatore Botanico Italiano 43(1): 143 .

Bartolucci, F. \& Conti, F. (2012) Notula 1921. Notulae alla checklist della Flora vascolare italiana: 13. Informatore Botanico Italiano 44(1): 185 .

Bentham, M. (1829) Edwards's Botanical Register; or, Flower Garden and Shrubbery. James Ridgway, London, without pagination.

Bentham, M. (1848) Labiatae. In: De Candolle, A.P. de (Ed.) Prodromus Systematis Universalis Regni Vegetabilis 12. Victoris Masson,

Parisiis pp. 212-226.

Boccone, P. (1697) Museo di piante rare della Sicilia, Malta, Corsica, Italia, Piemonte e Germania. Baptista Zuccato, Venetia pp. 130. 
http://dx.doi.org/10.5962/bhl.title.733

Boissier, E. (1879) Flora orientalis 1. H. Georg., Basel, Genève, pp. 466.

Bräuchler, C., Meimberg, H., Abele, T. \& Heubl, G. (2005) Polyphyly of the genus Micromeria Benth. (Lamiaceae) evidence from cpDNA sequence data. Taxon 54(3): 639-650.

http://dx.doi.org/10.2307/25065421

Bräuchler, C., Meimberg, H. \& Heubl, G. (2008a) New names in Old World Clinopodium-the transfer species of Micromeria sect. Pseudomelissa to Clinopodium. Taxon 55(4): 977-981.

http://dx.doi.org/10.2307/25065692

Bräuchler, C., Ryding, O. \& Heubl, G. (2008b) The genus Micromeria (Lamiaceae), a synoptical update. Willdenowia 38: 368-410. http://dx.doi.org/10.3372/wi.38.38202

Brullo, C. \& Brullo S. (2009) Considerazioni su alcune specie critiche della flora sicula. In: Peccenini, S., G. Domina (Eds.) Gruppi critici della Flora d'Italia. Luxograph, Palermo pp. 43-44.

Cantino, P.D. \& Wagstaff, S.J. (1998) A reexamination of North American Satureja s.l. (Lamiaceae) in light of molecular evidence. Brittonia 50: 63-70.

http://dx.doi.org/10.2307/2807719

Davis, P.H. (Ed.) (1982) Flora of Turkey and the East Aegean Islands 7. Edinburgh University Press, Edinburgh, 947 pp.

Govaerts, R. (1999) Lamiaceae. World checklist of seed plants 3(1). Kew.

Greuter, W., Burdet, H. \& Long, G. (1984) Med-checklist. Dicotyledones (Convolvulaceae-Labiatae) 3. Conservatoir et Jardin Botaniques, Genève, $395 \mathrm{pp}$.

Harley, R.M.A. \& Paucar, A.G. (2000) List of species of tropical American Clinopodium (Labiatae), with new combinations. Kew Bulletin 55(4): 917-927. http://dx.doi.org/10.2307/4113638

Harley, R.M.A., Atkins, S., Budantsev, A., Cantino, P.D., Conn, B.J., Grayer, R., Harley, M.M., de Kok, R., Krestovskaja, T., Morales, R., Paton, A.J., Ryding, O. \& Upson, T. (2004) Labiatae. In: Kadereit, J.W. (Ed.) The families and genera of vascular plants 7. Springer, Berlin, pp. 167-275.

Jacquin, N.J. (1771) Observationum Botanicarum, Iconibus Illustratarum 4. Ex Officina Krausiana, Vindobonae, 14 pp.

Kuntze, O. (1891) Clinopodium. Revisio generum plantarum 2. A. Felix, Leipzig, 634 pp.

Linnaeus, C. (1753) Species Plantarum 2. Laurentii Salvii, Stockholmiae, 673 pp.

McNeill, J., Barrie, F.R., Buck, W.R., Demoulin, V., Greuter, W., Hawksworth, D.L., Herendeen, P.S., Knapp, S., Marhold, K., Prado, J., Prud'homme Van Reine, W.F., Smith, G.F. Wiersema, J.H, \& Turland, N.J. (2012) International code of nomenclature for algae, fungi, and plants (Melbourne code). Koeltz Scientific Books, Melbourne, 140 pp.

Miller, P. (1754) The Gardeners Dictionary, ed. 4. Printed by the author, London, without pagination.

Miller, P. (1768) The Gardeners Dictionary, ed. 8. Printed by the author, London, without pagination.

Moench, C. (1794) Methodus Plantas Horti Botanici et Agri Marburgensis: a staminum situ describendi 2. Officina Nova Libraria Academiae, Marburgi Cattorum, 780 pp.

Peruzzi, L. \& Conti, F. (2008) Notulae alla Checklist della Flora Vascolare Italiana. Informatore Botanico Italiano 40(2): $263-264$.

Pool, A. (2008) A new combination in Clinopodium (Lamiaceae) from mesoamerica and Cuba. Novon 18(4): 508-510. http://dx.doi.org/10.3417/2005139

Prather, L.A., Monfils, A.K., Posto, A.L. \& Williams, R.A. (2002) Monophyly and phylogeny of Monarda (Lamiaceae): Implications of sequence data from the internal transcribed spacer (ITS) region of nuclear ribosomal DNA. Systematic Botany 27(1): $127-137$.

Rosselló, J.A. (2006) A new combination in Clinopodium (Lamiaceae). Flora Montiberica 33: 18-19.

Šilić, C. (1979) Monografija rodova Satureja L., Calamintha Miller, Micromeria Bentham, Acinos Miller $i$ Clinopodium L. u flori Jugoslavije. Zemaljski Muzej Bosne i Hercegovine, Sarajevo, 440 pp.

Trusty, J.L., Olmstead, R.G., Bogler, D.J., Santos-Guerra, A. \& Francisco-Ortega, J. (2004) Using molecular data to test a biogeographic connection of the Macaronesian genus Bystropogon (Lamiaceae) to the New World: a case of conflicting phylogenies. Systematic Botany 29(3): 702-715.

http://dx.doi.org/10.1600/0363644041744347

Wagstaff, S.J., Olmstead, R.G. \& Cantino, P.D. (1995) Parsimony analysis of cpDNA restriction site variation in subfamily Nepetoideae (Labiatae). American Journal of Botany 82(7): 886-892.

http://dx.doi.org/10.2307/2445975

World Checklist of Selected Plant Families (2010) Euro+Med Plantbase - the information resource for Euro-Mediterranean plant diversity. Available from http://ww2.bgbm.org/EuroPlusMed/PTaxonDetail.asp?NameId=78270\&PTRefFk=8000000 (accessed: 13 January 2014). 